\title{
Variation in soil thermal properties under different soil solarization materials varying in thickness under field conditions in Nigeria
}

\author{
Onwuka Brown Mang* and Ikhuoria Onomen Christiana \\ Department of Soil Science and Meteorology, Michael Okpara University of Agriculture Umudike, \\ PMB 7267, Umuahia, Abia State, Nigeria. \\ [Received: July 29, 2018 Accepted: October 02, 2018]
}

\begin{abstract}
An in-depth knowledge on the soil thermal properties under different soil solarization techniques is essential for soil treatment against soil-borne pathogens. This paper presents an investigation on effects of different soil solarization materials on soil thermal properties, organic matter and aggregate stability under field conditions. This study evaluates three materials: translucent whitish plastic (TWP), transparent nylon (TN) and black nylon (BN) each at three thickness levels $(0.05,0.10$ and $0.15 \mathrm{~mm})$ and control (bare soil). The parameters investigated in this study included soil temperature, organic matter, bulk density, volumetric moisture content, thermal conductivity, volumetric heat capacity, heat flux, thermal diffusivity and thermal effusivity. The results showed that the soil solarization materials varying in thickness influenced the soil heat energy transfer and had a significant effect on soil bulk density and volumetric moisture content. The results revealed that transparent nylon at a thickness of 0.05 $\mathrm{mm}$ recorded the highest soil temperature $\left(62^{\circ} \mathrm{C}\right)$ and was significantly higher than black nylon at a thickness of $0.15 \mathrm{~mm}\left(44^{\circ} \mathrm{C}\right)$ and the bare soil $\left(41^{\circ} \mathrm{C}\right)$. Transparent nylon at a thickness of $0.05 \mathrm{~mm}$ also recorded the highest organic matter content $\left(19.60 \mathrm{~g} \mathrm{~kg}^{-1}\right)$. The bulk density of the bare soil $\left(1.57 \mathrm{Mg} \mathrm{m}^{-3}\right)$ was significantly higher than the bulk densities of soils covered with solarization materials. Transparent nylon at thickness of $0.05 \mathrm{~mm}$ had the highest volumetric moisture content $\left(0.116 \mathrm{~m}^{3} \mathrm{~m}^{-3}\right)$ while translucent whitish plastic at a thickness of $0.15 \mathrm{~mm}$ recorded the lowest $\left(0.401 \mathrm{~m}^{3} \mathrm{~m}^{-3}\right)$. Transparent nylon at a thickness of $0.05 \mathrm{~mm}$ transmitted the highest quantity of

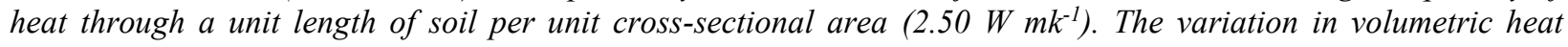
capacity between the solarization materials was highly noted in transparent nylon (TN) at a thickness of $0.05 \mathrm{~mm}$ $\left(2.65 \mathrm{~J}\left(\mathrm{~m}^{3} \mathrm{~K}\right)^{-1}\right)$ and less in bare soil (control) with a value of $\left(1.65 \mathrm{~J}\left(\mathrm{~m}^{3} \mathrm{~K}\right)^{-1}\right)$. Transparent nylon with thickness of $0.05 \mathrm{~mm}$ transferred the highest heat per unit area of soil $\left(42338.25 \mathrm{~W} \cdot \mathrm{m}^{-2}\right)$, while bare soil transferred the lowest. The highest thermal diffusivity $\left(1.35 \mathrm{~m}^{2} \mathrm{~s}^{-1}\right)$ was recorded in the soil with no solarization material. The soil under transparent nylon with thickness of $0.05 \mathrm{~mm}$ recorded the highest exchange of thermal energy $\left(2.57 \mathrm{Jm}^{-2} \mathrm{~K}^{-1} \mathrm{~S}^{-1 / 2}\right)$ with the environment and was significantly higher than other solarization materials. The transparent nylon had the highest soil macro aggregate stability. This study will help farmers in terms of choice and adoption of affordable conservation methods in treating the soil against soil-borne pathogens.
\end{abstract}

Keywords: Soil solarization techniques, soil heat energy, thermal properties, aggregate stability

\section{Introduction}

The knowledge of soil structural stability and thermal properties is important for effective soil energy balance. The soil thermal and structural properties play a major role in governing the exchange of energy and mass between the soil and atmosphere (Alrtimi et al., 2016). The effect of soil temperature and the thermal properties on soil had been observed at the level of soil formation (Dec et al., 2009), through their direct effect on the weathering of parent materials to produce mineral particles (Zawadzki et al., 1999). Soil temperature and thermal properties also influence soil biological processes, uptake of water and nutrients by roots resulting to plant growth (Onwuka, 2016). Hillel (1998) observed that increase in soil temperature enhanced the activity of microorganisms which increased decomposition of organic materials. Aggregate stability is an indicator of soil structural stability (Six et al., 2000; Bronic and Lal, 2005). Soil aggregate stability determines soil resistivity to mechanical stresses, and also the impacts of rainfall and surface runoff (Canasveras et al., 2010).

Soil solarization technique is a practical approach of increasing soil temperature through passive solar heating on

*Email: onwuka.brown@mouau.edu.ng 
moist soil mulched or covered with plastic polyethylene (Stapleton, 2000), which plays a key role in improving and controlling soil properties (Moreno et al., 2016). The passive process of solarisation causes the heating of the soil to maximum levels during the day time and then cooled at night (Stapleton, 2000). The highest temperature observed during solarization was achieved at the top soil which decreased down the depth. (Stapleton, 1997).

Studies have shown that synthetic soil surface covering had a positive effect on soil heat energy transfer and soil evaporation (Iqbal, 1986; Qin et al., 2015; Xiukang et al., 2015; Liang et al., 2017), which implies that synthetic covering of the soil was useful in conserving soil moisture and increase the temperature of the soil (Wu et al., 2017). Soil thermal properties depend on bulk density, total porosity, volumetric water content (Łydżba et al., 2016), particle size distribution and texture (Tokoro et al., 2016). Some soil solarization techniques had a positive influence on soil temperature (Usowicz et al., 2013; Pramanik et al., 2015) and affected the soil thermal regime by controlling the radiation balance, thermal conductivity, thermal diffusivity and volumetric heat capacity in the soil (Ahmed et al., 2017).

Adequate artificial soil surface covers or mulching increases soils structural stability (Bronic and Lal, 2005), helps in controlling erosion because of the reduction in erosive effect of raindrops falling on bare soils and the ability of winds to remove soil particles (Ngailo and Dechen, 2010). Plants and organic materials have been recorded to be one of the major factors that affect soil aggregate stability (Six et al., 2004). Reports have shown that black polyethylene and black-woven polypropylene improved the structural stability of the soil by enhancing the growth of plants which is a source of organic material (Stepanek et al., 2002). Soil solarization techniques improve soil structure by creating favorable conditions for soil aggregation, through changes in soil water content and temperature thereby improving the efficient mineralization of soil organic matter (Green et al., 2003).

The proper understanding of the variations in soil thermal properties and aggregate stability under different soil solarization techniques is necessary in the determination of effects of different artificial soil surface management materials for reducing the impact of accelerated erosion (increasing the structural stability of the soil) and soil heat energy balance. Information from this study may be important in selecting erosion preventive measures in absence of organic mulches and for selecting appropriate types of artificial soil covering materials.as well as the management strategies to be adopted. Therefore, the objective of the study was to investigate the effects of different soil solarization materials on soil thermal properties, organic matter and aggregate stability.

\section{Materials and Methods}

\section{Study area}

The field study was carried out in Ikpe Ikot Nkon in Ini Local Government of Akwa Ibom State, Southeastern, Nigeria. The area is located within latitudes $4032^{\prime} \mathrm{E}$ and $5033^{\prime} \mathrm{N}$ and Longitudes 7o25' and 8o25' E (Ogban and Obi, 2010). The research farm has a total area of $3,204 \mathrm{~m}^{2}$. The location has a mean annual rainfall of $3000 \mathrm{~mm}$ (Nigeria Meteorological Agency, 2015). The rainfall is bimodal, starts in April and ends in October with peaks in June and September (Nigeria Meteorological Agency, 2015). The geology of the area consists mainly of the thick clayey shale, fine textured dark grey to bluish gray shale and thin sandstone bands which stretches to Itu and Enyong creek confluence (Olugbenga and Egbulem, 2015).

\section{Field study}

The experimental field was cleared of plant debris leaving the soil bare after which it was irrigated using surface irrigation method before the treatments were applied. The treatments used for the soil solarization include three (3) types of nylon materials; translucent whitish plastic (TWP), transparent nylon (TN) and black nylon (BN). Each of the nylon materials are in three (3) thickness levels $(0.05$, 0.10 and $0.15 \mathrm{~mm}$ ) compared against no nylon (bare soil) which is the control, making it ten (10) treatments applied in triplicate under randomized complete block design (RCBD). The total number of experimental treatment units were thirty (30). The area of each experimental treatment unit in the field was $20 \mathrm{~m}^{2}$ making a total experimental area of $600 \mathrm{~m}^{2}$. The nylon materials were rolled, so that it is perfectly attached to the soil surface so as to increase solarization efficiency. In each experimental treatment unit, three (3) sampling points were located randomly. At each of the three (3) points within an experimental treatment unit, field measurements of soil temperature and thermal conductivity at $0-10 \mathrm{~cm}$ and $10-20 \mathrm{~cm}$ depths were taken three times in a day till the end of the experiment. The data were collected in the morning $(6.30-7.30 \mathrm{am})$, afternoon (2.00 $3.00 \mathrm{pm})$ and evening $(6.00-7.00 \mathrm{pm})$. Soil core samples for bulk density and auger samples for organic matter were collected every seven (7) days till the end of the experiment at $0-10 \mathrm{~cm}$ and $10-20 \mathrm{~cm}$ depths from the designated sampling points within each experimental treatment unit. The samples for aggregate stability were collected at the end of the experiment. The experiment lasted for ninety (90) days, after which it was terminated. 
Determination and calculation of soil properties studied

Bulk density: Soil bulk density (Bd) was determined by the method described by Blake and Hartage (2003) using the equation:

Bulk density $(\mathrm{Bd})=\frac{\text { mass of dry soil }(\mathrm{Mg})}{\text { volume of the soil sample }}$

Volumetric moisture content (VMC): The volumetric moisture content (VMC) was calculated by gravimetric methods of field soil at a depth of $0-20 \mathrm{~cm}$ as described by Gardner (2000) using the equation:

Volumetric moisture content $(\mathrm{VMC})=\frac{m c \times \mathrm{Bds}}{\mathrm{Bdw}}$

Where $\mathrm{mc}=$ moisture content in percentage; $\mathrm{Bds}=$ soil bulk density $\left(\mathrm{Mg}^{\mathrm{m}-3}\right)$; Bdw $=$ water density $\left(\mathrm{Mg}^{\mathrm{m}-3}\right)$.

Organic Matter: The organic matter content was determined by Walkely and Black method (Nelson and Summers, 1982).

Thermal conductivity (K): This was determined in the field using KD 2 Pro meter apparatus as described by Oladunjoye and Sanuade (2012).

Volumetric heat capacity (CV): The soil volumetric heat capacity was calculated from the volumetric water content (VMC) and soil bulk density (Bd) as described by Evett et al. (2012).

Volumetric heat capacity $(\mathrm{CV})=\frac{2.02 \times 10 \mathrm{Bd}}{2.65+4.19 \times 10 \mathrm{VMC}}$

Thermal diffusivity (D): This was calculated from thermal conductivity (K) and volumetric heat capacity (VHC);

Thermal diffusivity $(\mathrm{D})=\mathrm{k} / \mathrm{CV}$

Thermal effusivity (E): This was calculated from thermal conductivity $(\mathrm{K})$ and volumetric heat capacity $(\mathrm{CV})$

Thermal effusivity $(\mathrm{E})=\sqrt{K \times C V}$

Temperature (T): This was determined in the field using soil mercury-in-glass thermometer as described by Nwankwo and Ogagarue (2012).

Heat flux (Q): The soil heat flux was calculated from thermal conductivity $(\mathrm{K})$, temperature $(\mathrm{T})$ and distance $(\mathrm{Z})$

Heat flux $(\mathrm{Q})=\mathrm{K} \frac{\Delta T}{\Delta z}$
Aggregate stability: The mean weight diameter (MWD) as an index of macro aggregate stability was determined by the wet sieving method of Kemper and Rosenau (1986). Soil samples collected at the end of the experiment were wet sieved, employing a nest of three aluminum ring sieves with 2, 1, $0.5 \mathrm{~mm}$ mesh openings. The aggregates were allowed to wet fully on the sieves for 5 min before shaken vertically at 40 revolutions per minute for $30 \mathrm{~min}$. The sieves were separated and oven - dried at $105^{\circ} \mathrm{C}$ together with the aggregate fractions collected in each sieve. The dry weight of the aggregate was measured and the mean weight diameter (MWD) (Kemper and Rosenau, 1986) determined, as an index structural stability of aggregates using the formula:

$\mathrm{MWD}=\sum_{i=1}^{n} W_{i} \cdot \bar{X}_{i}$

Where:

$\bar{X}_{i}=$ the mean diameter between the three sieves $(\mathrm{mm})$

$W_{i}=$ the weight fraction of aggregates remaining on the sieve (\%).

\section{Statistical analysis}

The data generated were subjected to analysis of variance (ANOVA) in randomized complete block design (RCBD) using the SPSS package of version 23. The means were separated using the Fisher's Least Significant difference (LSD) at $1 \%$ probability level. The results were fitted into a bar graph using the Microsoft excel package of 2013 version.

\section{Results and Discussion}

\section{Ambient temperature}

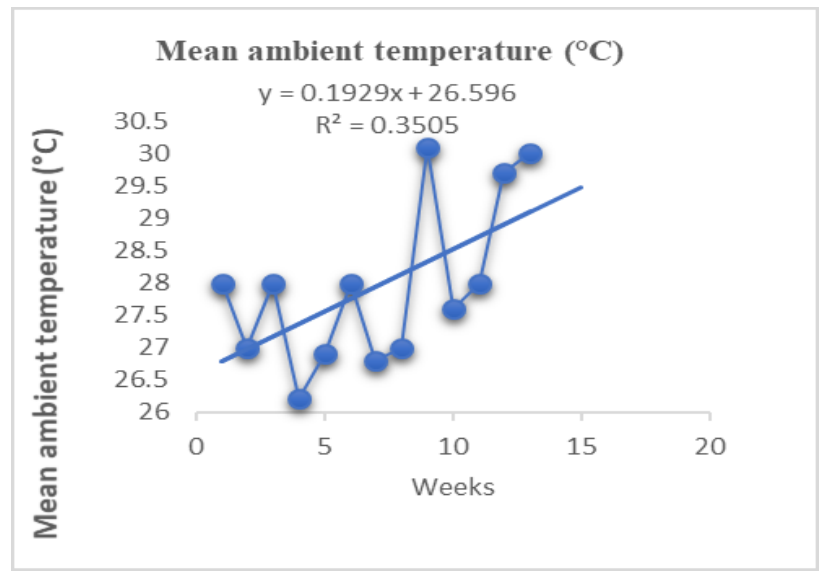

Figure 1: Weekly ambient temperature of the environment during the experiment 
The temperature trend of the location under study over a period of 13 weeks is shown in Figure 1. The graph showed that the mean temperature was highest $\left(30.10^{\mathrm{C}}\right)$ in week 9 , whereas the 4 th week had the lowest $\left(26.20^{\mathrm{C}}\right)$ mean temperature. However, from 7 th week to the 8 th week and from 10th week to 11 th week the mean temperature was fairly constant. The location under study had experienced more $26.20^{\mathrm{C}}$ temperature per day. The figure showed an increasing trend in the temperature of the area. The mean annual temperature increased in the range of $26.2-30.10^{\mathrm{C}}$ per week during the study period.

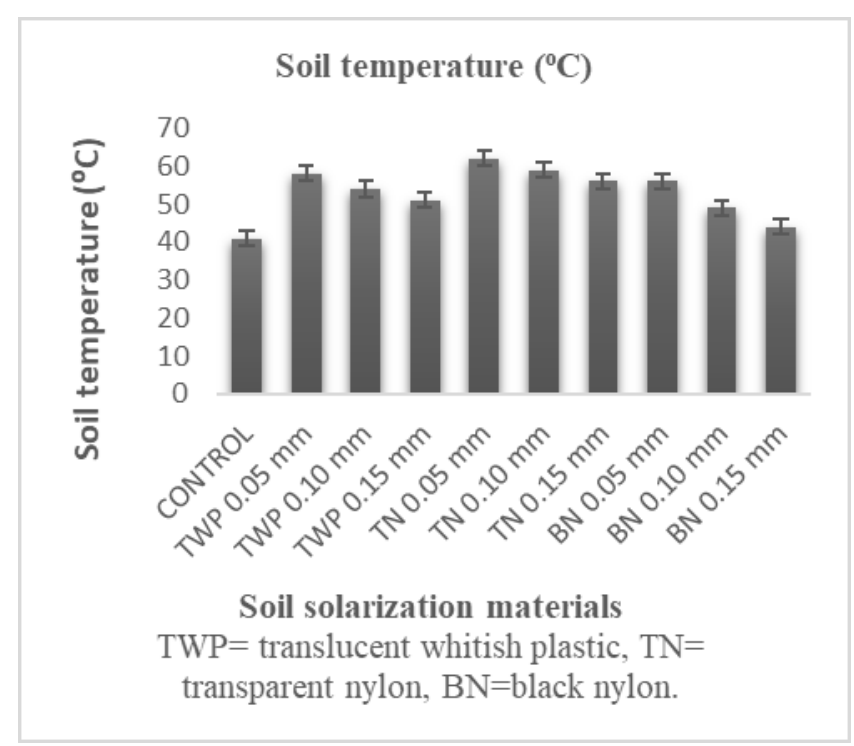

\section{Figure 2: Effects of different soil solarization materials on soil temperature}

\section{Soil temperature}

The data of soil temperature under different soil solarization materials are shown in Figure 2. The result showed that the temperature ranged from $41^{\mathrm{oC}}-62^{\circ \mathrm{C}}$ with a mean of $53^{\circ \mathrm{C}}$. In Figure 2 it was observed that transparent nylon (TN) with a thickness of $0.05 \mathrm{~mm}$ had the highest temperature $\left(62^{\circ \mathrm{C}}\right)$, while bare soil (control) had the lowest $\left(41^{\mathrm{oC}}\right)$. According to the results, the temperature of the soil increased significantly $(p \leq 0.01)$ as it was covered with transparent nylon (TN) and translucent whitish plastic (TWP) at thickness of $0.05 \mathrm{~mm}, 0.10 \mathrm{~mm}$ and $0.15 \mathrm{~mm}$. However, black nylon (BN) at a thickness of $0.05 \mathrm{~mm}$ $\left(56^{\circ \mathrm{C}}\right)$ and $0.10 \mathrm{~mm}\left(49^{\circ \mathrm{C}}\right)$ significantly increased the temperature, but at a thickness of $0.15 \mathrm{~mm}\left(44^{\circ \mathrm{C}}\right)$ black nylon (BN) was similar to control. The increase in soil temperature observed in transparent nylon may be attributed to the greater net radiation that passes through the transparent nylon (Ramakrishna et al., 2006). (Nana et al.,
2016) observed that heat rays from the transparent nylon pass quickly through the nylon and trapped to heat the soil. The black nylon significantly had a lower temperature than the transparent nylon. This may be as a result of the fact that black nylon absorbs and deflects part of the heat coming down to the soil from the sun rather than trapping it as transparent nylon does (Juan and Dean, 2002). Pramanik (2015) reported that transparent nylon increased soil temperature more than black nylon as a result of its pigment content. Liakatas et al. (1986) observed that black nylon and translucent whitish plastic may have reduced the soil temperature and the radiant heat energy of the soil. However, transparent nylon could have attracted a relatively large net radiation and increased the temperature of the soil surface. Kamal and Singh (2011) observed Black nylon and translucent plastic caused poor heating of soil during hot hours, but preserved heat at night.

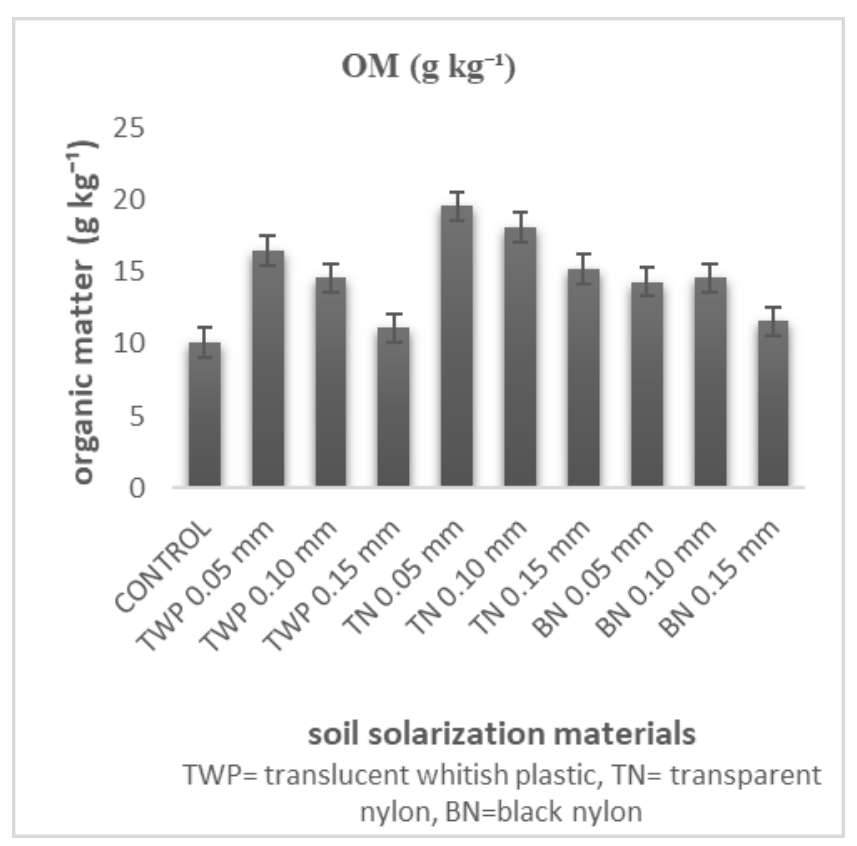

Figure 3: Effects of different soil solarization materials on soil organic matter

\section{Organic matter}

Figure 3 showed the influence of soil solarization materials on organic matter. The result showed that organic matter ranged from $10.10-19.60 \mathrm{~g} \mathrm{~kg}^{-1}$ with a mean of $14.57 \mathrm{~g} \mathrm{~kg}^{-1}$. In Figure 3, it was observed that transparent nylon (TN) with a thickness of $0.05 \mathrm{~mm}$ had the highest organic matter content $\left(19.60 \mathrm{~g} \mathrm{~kg}^{-1}\right)$, while bare soil had the lowest $\left(10.10 \mathrm{~g} \mathrm{~kg}^{-1}\right)$. From the results, the soil organic matter content under translucent whitish plastic (TWP) with thickness of $0.05 \mathrm{~mm}\left(16.50 \mathrm{~g} \mathrm{~kg}^{-1}\right)$ and $0.10 \mathrm{~mm}(14.60 \mathrm{~g}$ 
$\left.\mathrm{kg}^{-1}\right)$, transparent nylon at thickness of $0.05 \mathrm{~mm}\left(19.60 \mathrm{~g} \mathrm{~kg}^{-}\right.$ $\left.{ }^{1}\right), 0.10 \mathrm{~mm}\left(18.10 \mathrm{~g} \mathrm{~kg}^{-1}\right)$ and $0.15 \mathrm{~mm}\left(15.20 \mathrm{~g} \mathrm{~kg}^{-1}\right)$ and black nylon at thickness of $0.05 \mathrm{~mm}\left(14.30 \mathrm{~g} \mathrm{~kg}^{-1}\right)$ and 0.10 $\mathrm{mm}\left(14.60 \mathrm{~g} \mathrm{~kg}^{-1}\right)$ were significantly $(p \leq 0.01)$ higher than the control (bare soil). However, organic matter contents of the soil under translucent whitish plastic (TWP) with thickness of $0.15 \mathrm{~mm}\left(11.10 \mathrm{~g} \mathrm{~kg}^{-1}\right)$ and black nylon (BN) at $0.15 \mathrm{~mm}$ thickness $\left(11.60 \mathrm{~g} \mathrm{~kg}^{-1}\right)$ were similar with that of bare soil.

The higher organic matter contents under transparent nylon, translucent whitish plastic and black nylon as compared with that of bare soil (control) agree with the findings of Khan et al. (2012) who reported that soil organic matter increased with soil solarization even at two (2) weeks interval. The higher organic matter content of the solarization materials may be attributed to the increased activities of micro-organisms in the decomposition of organic materials as a result of higher temperature (Fang et al., 2005). Broadbent (2015) reported that temperature of 50 to $60^{\circ \mathrm{C}}$ increases the decomposition of organic matter by increasing the movement of soluble substrates in the soil and stimulating microbial activities and soil biochemical processes (Fierer et al., 2005).

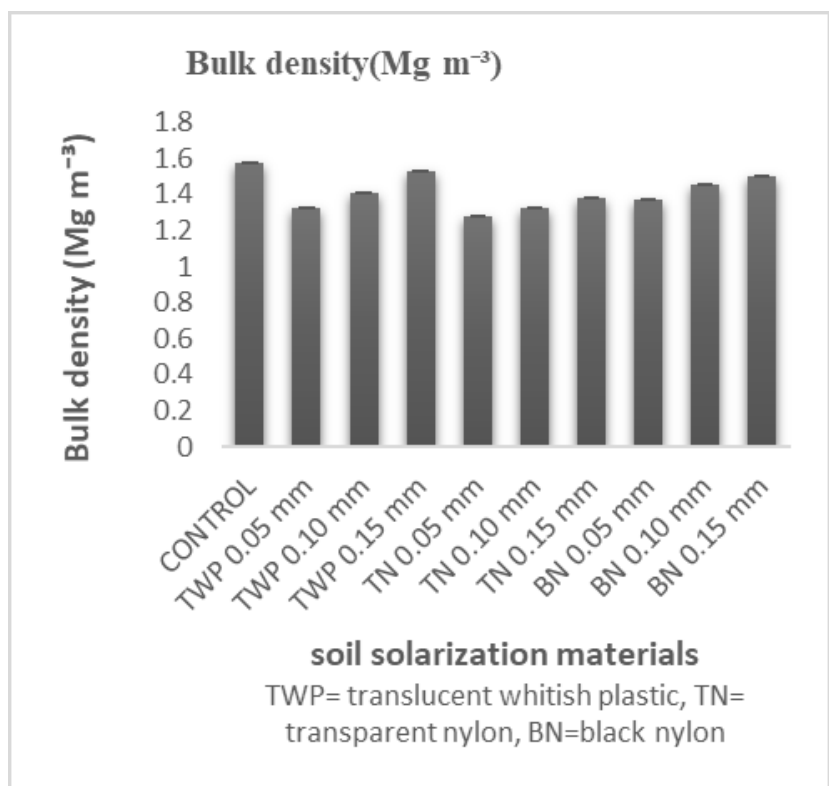

Figure 4: Effects of different soil solarization materials on soil bulk density

\section{Bulk density}

Figure 4 showed the influence of soil solarization materials on bulk density. According to the result, the bulk density was higher in the control (bare soil) than the soil covered with nylon and plastic. The result showed that the bulk density ranged from $1.27-1.57 \mathrm{Mg}^{\mathrm{m}-3}$ with a mean of $1.41 \mathrm{Mg}^{\mathrm{m}-3}$. In Figure 4 it was observed that bare soil had the highest bulk density $\left(1.57 \mathrm{Mg}^{\mathrm{m}-3}\right)$, while transparent nylon (TN) with a thickness of $0.05 \mathrm{~mm}$ had the lowest $\left(1.27 \mathrm{Mg}^{\mathrm{m}-3}\right)$. From the results, the soil bulk density under translucent whitish plastic (TWP) with thickness of 0.05 $\mathrm{mm}\left(1.32 \mathrm{Mg}^{\mathrm{m}-3}\right)$ and $0.10 \mathrm{~mm}\left(1.41 \mathrm{Mg}^{\mathrm{m}-3}\right)$ and transparent nylon at thickness of $0.05 \mathrm{~mm}\left(1.27 \mathrm{Mg}^{\mathrm{m}-3}\right), 0.10 \mathrm{~mm}(1.32$ $\left.\mathrm{Mg}^{\mathrm{m}-3}\right)$ and $0.15 \mathrm{~mm}\left(1.38 \mathrm{Mg}^{\mathrm{m}-3}\right)$ were significantly $(p \leq 0.01)$ lower than the control (bare soil). However, bulk density of soil under black nylon (BN) at $0.05 \mathrm{~mm}$ thickness (1.37 $\mathrm{Mg}^{\mathrm{m}-3}$ ) was significantly lower than the control, while at a thickness of $0.15 \mathrm{~mm}$, both translucent whitish plastic $\left(1.53 \mathrm{Mg}^{\mathrm{m}-3}\right)$ and black nylon $\left(1.50 \mathrm{Mg}^{\mathrm{m}-3}\right)$ were similar with that of bare soil.

The lower bulk densities under transparent nylon, translucent whitish plastic and black nylon as compared with that of bare soil (control) agree with (Ahmed et al., and Grunwald et al., 2017). The lower bulk densities may be as a result of the increasing soil temperature (Figure 2) which probably might have accelerated the decomposition of organic materials by microorganisms, thereby decreasing soil bulk density compared to bare soil (Conant et al., 2011).

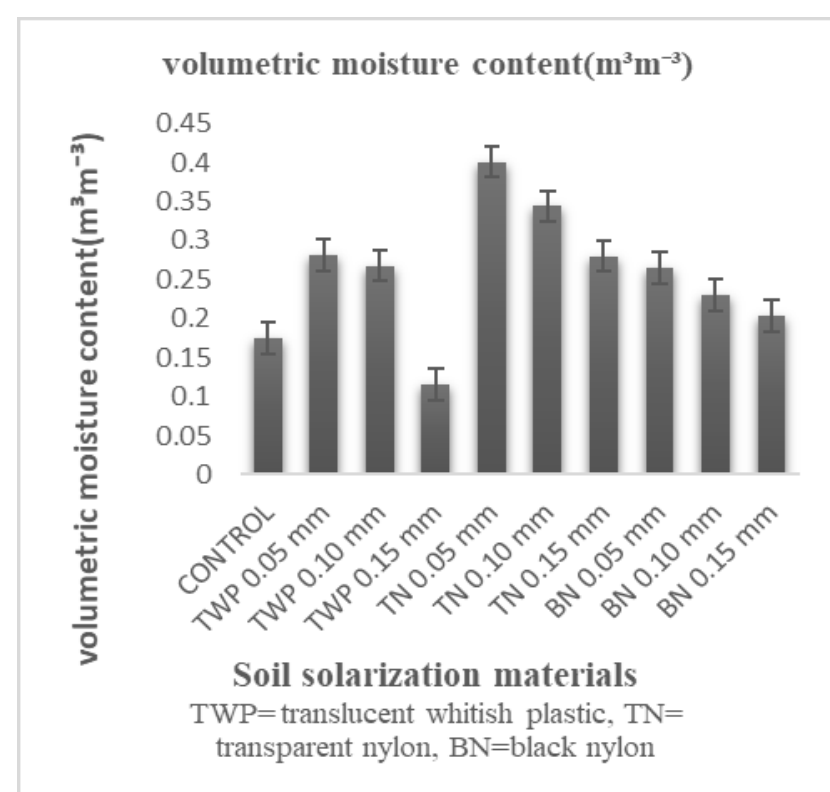

\section{Figure 5: Effects of different soil solarization materials on volumetric moisture content}

\section{Volumetric moisture content}

Figure 5 indicated the changes in volumetric moisture content in soil under different soil solarization materials. The result showed that the volumetric moisture content varied from $0.116-0.401^{\mathrm{m} 3 \mathrm{~m}-3}$ with a mean of $0.256^{\mathrm{m} 3 \mathrm{~m}-3}$. 
The soil covered with transparent nylon at $0.05 \mathrm{~mm}$ thickness had the highest $\left(0.116^{\mathrm{m} 3 \mathrm{~m}-3}\right)$ volumetric moisture content, whereas translucent whitish plastic (TWP) with thickness of $0.15 \mathrm{~mm}$ had the lowest $\left(0.401^{\mathrm{m} 3 \mathrm{~m}-3}\right)$. When compared with the control (bare soil), all treatments except the translucent whitish plastic (TWP) and black nylon (BN) at $0.15 \mathrm{~mm}$ thickness $\left(0.116\right.$ and $0.203^{\mathrm{m} 3 \mathrm{~m}-3}$ respectively) showed no significant $(p \leq 0.01)$ increase in volumetric moisture content. However, the increase in volumetric moisture content varied between treatments but was highly observed in transparent nylon and lesser in translucent whitish plastic and black nylon.

The increase in volumetric moisture content may be as a result of greater capillary forces under the nylon and plastic cover accumulated water from lateral flow through the buffer zone (Kader et al., 2017). These plastic and nylon cover also prevented soil surface evaporation (Doring et al., 2005), thereby conserving moisture in the soil (Shah et al., 2013).

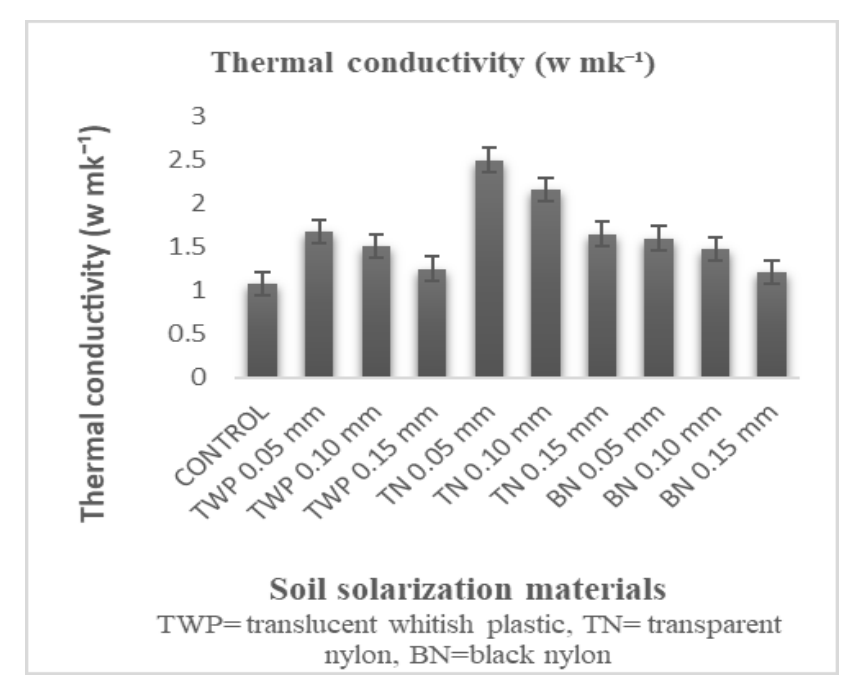

Figure 6: Effects of different soil solarization materials on thermal conductivity

\section{Thermal conductivity}

The variations in thermal conductivity under different soil solarization materials are shown in Figure 6. According to the result, the thermal conductivity was higher in the soil covered with solarization materials than the control (bare soil). The result showed that the quantity of heat transmitted through a unit length of soil per unit cross-sectional area ranged from $1.08-2.50 \mathrm{~W}^{\mathrm{mk}-1}$ with a mean of $1.61 \mathrm{~W}^{\mathrm{mk}-1}$. The thermal conductivities are moderate as it falls within the standard range of measurement of $0.02-4.00 \mathrm{~W}^{\mathrm{mk}-1}$ (Oladunjoye et al., 2013). In Figure 6, it was observed that transparent nylon (TN) with a thickness of $0.05 \mathrm{~mm}$ had the highest thermal conductivity $\left(2.50 \mathrm{~W}^{\mathrm{mk}-1}\right)$, while control (bare soil) had the lowest $\left(1.08 \mathrm{~W}^{\mathrm{mk}-1}\right)$. From the results, the thermal conductivity under translucent whitish plastic (TWP) with thickness of $0.05 \mathrm{~mm}\left(1.68 \mathrm{~W}^{\mathrm{mk}-1}\right)$ and 0.10 $\mathrm{mm}\left(1.51 \mathrm{~W}^{\mathrm{mk}-1}\right)$ and transparent nylon at thickness of 0.05 $\mathrm{mm}\left(2.50 \mathrm{~W}^{\mathrm{mk}-1}\right), 0.10 \mathrm{~mm}\left(2.16 \mathrm{~W}^{\mathrm{mk}-1}\right)$ and $0.15 \mathrm{~mm}(1.65$ W mk-1) were significantly $(p \leq 0.01)$ higher than the control (bare soil). However, thermal conductivity of soil under black nylon $(\mathrm{BN})$ at $0.05 \mathrm{~mm}$ thickness $\left(1.60 \mathrm{~W}^{\mathrm{mk}-1}\right)$ was significantly higher than the control, while at a thickness of $0.15 \mathrm{~mm}$, both translucent whitish plastic $\left(1.25 \mathrm{~W}^{\mathrm{mk}-1}\right)$ and black nylon $\left(1.21 \mathrm{~W}^{\mathrm{mk}-1}\right)$ were similar with that of bare soil.

The higher quantity of heat transmitted through the soil under transparent nylon, translucent whitish plastic and black nylon as compared with that of bare soil (control) according to (Rubio et al., 2009) may be as a result of increase in volumetric soil moisture content (Figure 5) and decrease in bulk density (Figure 4). Salomone et al. (1984) observed that the presence of moisture in the soil resulted to the development of a thin water film which bridges the gaps between the soil particles. Oluyamo et al. (2016) reported that the higher soil moisture content could have enhanced the effective contact area between the soil particles, resulting to higher heat flow thereby resulting to increased thermal conductivity. Furthermore, with a decrease in soil bulk density, less soil particles may be packed into a unit volume and this could decrease the number of contact points and increase pores between the soil particles making room for higher saturated hydraulic conductivity. This increase in soil volume and subsequent higher saturated hydraulic conductivity probably may have provided a larger heat flow and possibly increased the soil thermal conductivity.

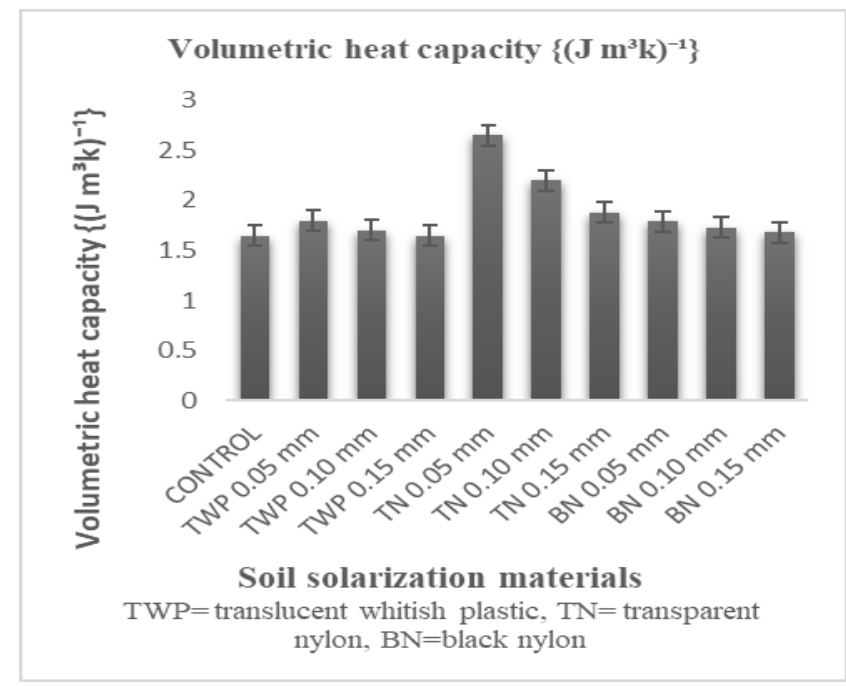

Figure 7: Effects of different soil solarization materials on volumetric heat capacity 


\section{Volumetric heat capacity}

Figure 7 indicates the changes in volumetric heat capacity of the soil as soil solarization materials were applied. All treatments showed significant $(p \leq 0.01)$ increase in volumetric heat capacity except translucent which plastic (TWP) at a thickness of $\left.0.15 \mathrm{~mm}\left(1.65 \mathrm{~J}^{3} \mathrm{~m}^{3} \mathrm{~K}\right)^{-1}\right)$ and black nylon (BN) with a thickness of $0.15 \mathrm{~mm}\left(1.68 \mathrm{~J}\left(\mathrm{~m}^{3} \mathrm{~K}\right)^{-1}\right)$. The increase varied between treatments but was highly noted in transparent nylon (TN) at a thickness of $0.05 \mathrm{~mm}(2.65 \mathrm{~J}$ $\left.\left(\mathrm{m}^{3} \mathrm{~K}\right)^{-1}\right)$ and less in control (bare soil) with a value of $1.65 \mathrm{~J}$ $(\mathrm{m} 3 \mathrm{~K})-1$. The two extremes show that if the soil is well covered with solarization materials there is a possibility of increasing the volumetric heat capacity and the reverse is true if the soil is left bare (Figure 7). The implications of increasing volumetric heat capacity in soil under different soil solarization techniques show that increasing soil volumetric moisture content (Figure 5) increases the heat storage capacity of soil, thereby increasing the volumetric heat capacity (Khaled and Abu-hamdeh, 2013). Rapid increase in the volumetric heat capacity of the covered soil with increasing volumetric moisture content (Figure 5) is probably due to adsorption of water forming thick hulls around the soil particles, which greatly enhanced its effective heat capacity (Abu-Hamdeh, 2003).

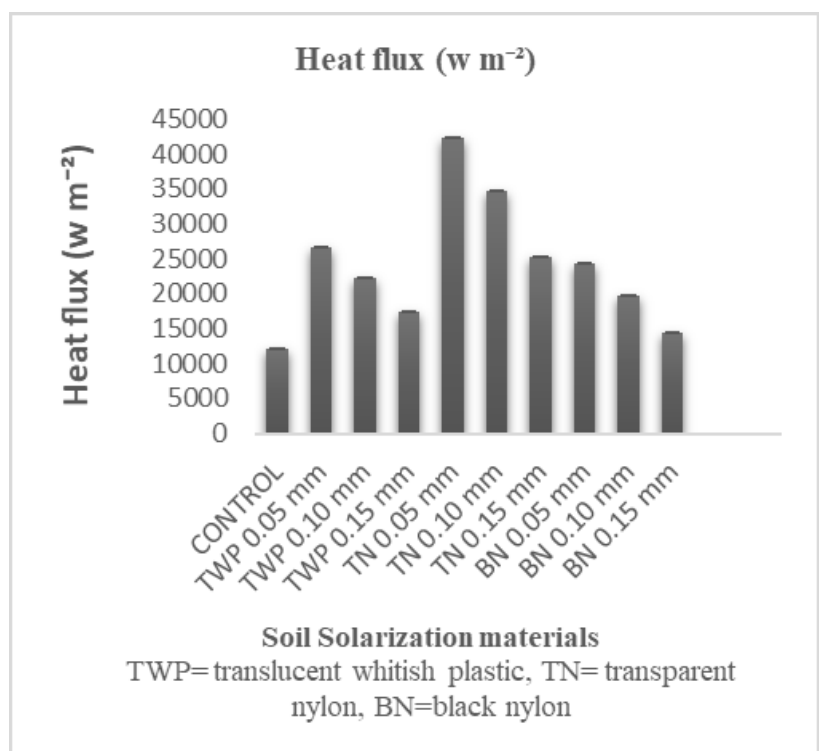

\section{Figure 8: Effects of different soil solarization materials on heat flux}

\section{Heat flux}

The data of soil heat flux under different soil solarization materials are shown in Figure 8. The result showed that the rate of heat transfer per unit area ranged from $12095.08-42338.25 \mathrm{~W}^{\mathrm{m}-2}$ with a mean of 23960.93
$\mathrm{W}^{\mathrm{m}-2}$. In Figure 8, it was observed that in a unit area of the soil, transparent nylon (TN) with a thickness of $0.05 \mathrm{~mm}$ had the highest heat transfer $\left(42338.25 \mathrm{~W}^{\mathrm{m}-2}\right)$, while bare soil (control) had the lowest $\left(12095.08 \mathrm{~W}^{\mathrm{m}-2}\right)$. From the results, the soil heat flux under translucent whitish plastic (TWP) with thickness of $0.05 \mathrm{~mm}\left(26615.74 \mathrm{~W}^{\mathrm{m}-2}\right)$ and 0.10 $\mathrm{mm}\left(22272.65 \mathrm{~W}^{\mathrm{m}-2}\right)$ and transparent nylon at thickness of $0.05 \mathrm{~mm}\left(42338.25 \mathrm{~W}^{\mathrm{m}-2}\right), 0.10 \mathrm{~mm}\left(34810.24 \mathrm{~W}^{\mathrm{m}-2}\right)$ and $0.15 \mathrm{~mm}\left(25239.06 \mathrm{~W}^{\mathrm{m}-2}\right)$ were significantly $(p \leq 0.01)$ higher than the control (bare soil). However, black nylon $(\mathrm{BN})$ at a thickness of $0.05 \mathrm{~mm}\left(24474.24 \mathrm{~W}^{\mathrm{m}-2}\right)$ and 0.10 $\mathrm{mm}\left(19808.84 \mathrm{~W}^{\mathrm{m}-2}\right)$ significantly increased the heat flux, but at a thickness of $0.15 \mathrm{~mm}\left(14542.51 \mathrm{~W}^{\mathrm{m}-2}\right)$ black nylon (BN) was similar to control. The increase in heat transfer observed in transparent nylon may be attributed to the higher radiation from sun that passes through the transparent nylon (Rubio et al., 2009). Ahmed et al. (2017) observed that rate of heat transmissivity is faster in the transparent nylon. The black nylon significantly had a lower heat flux than the transparent nylon. This may be as a result of the deflective action of the black nylon towards the heat coming down to the soil from the sun (Joan and Dean, 2002).

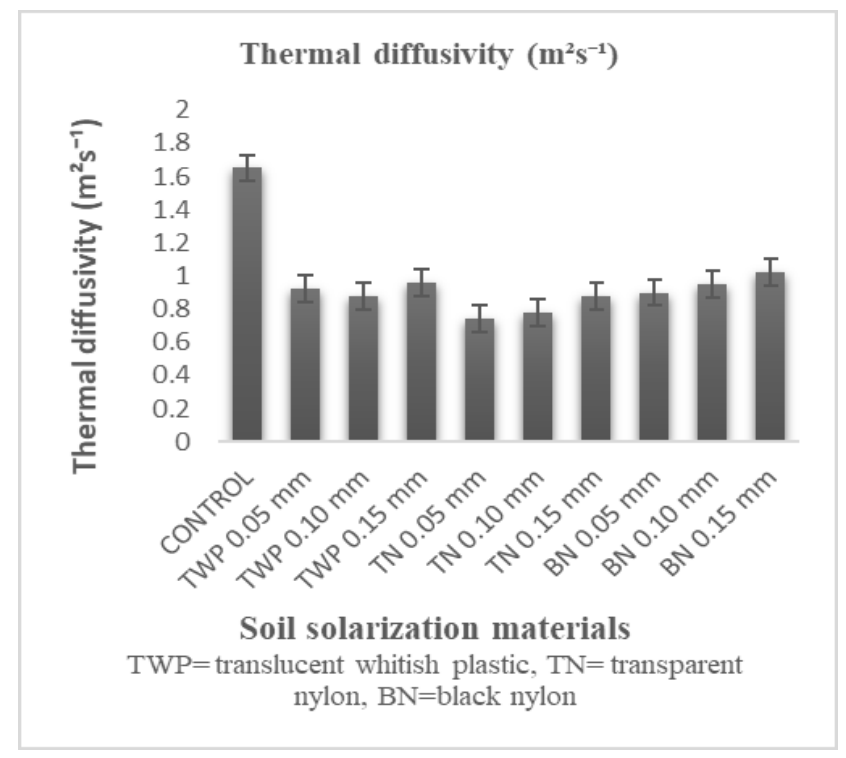

Figure 9: Effects of different soil solarization materials on thermal diffusivity

\section{Thermal diffusivity}

Figure 9 showed the influence of soil solarization materials on thermal diffusivity. According to the result, the thermal diffusivity of the bare soil (control) was higher than the soil covered with nylon and plastic. The result showed that thermal diffusivity ranged from $0.74-1.35^{\mathrm{m} 2 \mathrm{~s}-1}$ with a mean of $0.95^{\mathrm{m} 2 \mathrm{~s}-1}$. In Figure 9, it was observed that 
transparent nylon (TN) with a thickness of $0.05 \mathrm{~mm}$ had the lowest thermal diffusivity $\left(0.74^{\mathrm{m} 2 \mathrm{~s}-1}\right)$, while bare soil had the highest $\left(1.35^{\mathrm{m} 2 \mathrm{~s}-1}\right)$. From the results, the soil thermal diffusivity under translucent whitish plastic (TWP) with thickness of $0.05 \mathrm{~mm}\left(0.92^{\mathrm{m} 2 \mathrm{~s}-1}\right), 0.10 \mathrm{~mm}\left(0.88^{\mathrm{m} 2 \mathrm{~s}-1}\right)$ and $0.15 \mathrm{~mm}\left(0.96^{\mathrm{m} 2 \mathrm{~s}-1}\right)$ and transparent nylon at thickness of 0.05 $\mathrm{mm}(0.74 \mathrm{~m} 2 \mathrm{~s}-1), 0.10 \mathrm{~mm}\left(0.78^{\mathrm{m} 2 \mathrm{~s}-1}\right)$ and $0.15 \mathrm{~mm}\left(0.80^{\mathrm{m} 2 \mathrm{~s}-}\right.$ $\left.{ }^{1}\right)$ were significantly $(p \leq 0.01)$ lower than the control (bare soil). However, thermal diffusivity of the soil under black nylon (BN) at 0.05 and $0.10 \mathrm{~mm}$ thickness $\left(0.90\right.$ and $0.95^{\mathrm{m} 2 \mathrm{~s}-}$ $\left.{ }^{1}\right)$ were significantly $(p \leq 0.01)$ lower than the control, while at a thickness of $0.15 \mathrm{~mm}$ black nylon $\left(1.12^{\mathrm{m} 2 \mathrm{~s}-1}\right)$ was similar with that of bare soil.

The higher thermal diffusivities under bare soil (control) as compared with that of transparent nylon, translucent whitish plastic and black nylon agree with Ahmed et al. (2017). The higher thermal diffusivity of the bare soil may be attributed to the higher bulk density of the bare soil (Tong et al., 2017). The lower thermal diffusivities may be as a result of lower bulk density and higher porosity which could make more heat to be dispersed (An et al., 2016). The soil with higher thermal diffusivity quickly adjusts their temperature to suit that of their surroundings because they conduct heat quickly when compared to their volumetric heat capacity and they generally do not require much energy from their surroundings to reach thermal equilibrium (Oladunjoye and Sanuade, 2012).

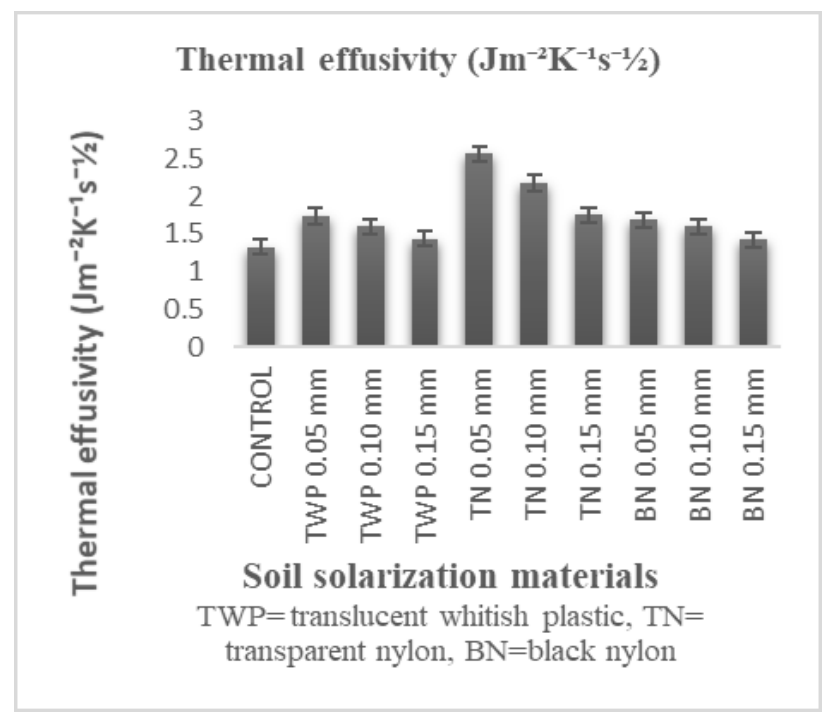

Figure 10: Effects of different soil solarization materials on thermal effusivity

\section{Thermal effusivity}

The variations in thermal effusivity (heat admittance) under different soil solarization materials are shown in
Figure 10. According to the result, the thermal effusivity was higher in the soil covered with nylon and plastic than the control (bare soil). The result showed that the measure of the ability of the soil to exchange thermal energy with its environment ranged from $1.33-2.57 \mathrm{~J}^{\mathrm{m}-2} \mathrm{~K}^{-1} \mathrm{~S}^{-1 / 2}$ with a mean of $1.73 \mathrm{~J}^{\mathrm{m}-2} \mathrm{~K}^{-1} \mathrm{~S}^{-1 / 2}$. In Figure 10, it was observed that transparent nylon (TN) with a thickness of $0.05 \mathrm{~mm}$ had the highest thermal effusivity $\left(2.57 \mathrm{~J}^{\mathrm{m}-2} \mathrm{~K}^{-1} \mathrm{~S}^{-1 / 2}\right)$, while control (bare soil) had the lowest $\left(1.33 \mathrm{~J}^{\mathrm{m}-2} \mathrm{~K}^{-1} \mathrm{~S}^{-1 / 2}\right)$. From the results, the thermal effusivity under translucent whitish plastic (TWP) with thickness of $0.05 \mathrm{~mm}\left(1.74 \mathrm{~J}^{\mathrm{m}-2} \mathrm{~K}^{-1} \mathrm{~S}^{-1 / 2}\right)$ and $0.10 \mathrm{~mm}\left(1.60 \mathrm{~J}^{\mathrm{m}-2} \mathrm{~K}^{-1} \mathrm{~S}^{-1 / 2}\right)$ and transparent nylon at thickness of $0.05 \mathrm{~mm}\left(2.57 \mathrm{~J}^{\mathrm{m}-2} \mathrm{~K}^{-1} \mathrm{~S}^{-1 / 2}\right), 0.10 \mathrm{~mm}\left(2.18 \mathrm{~J}^{\mathrm{m}-2}\right.$ $\left.\mathrm{K}^{-1} \mathrm{~S}^{-1 / 2}\right)$ and $0.15 \mathrm{~mm}\left(1.76 \mathrm{~J}^{\mathrm{m}-2} \mathrm{~K}^{-1} \mathrm{~S}^{-1 / 2}\right)$ were significantly $(p \leq 0.01)$ higher than the control (bare soil). However, thermal effusivity of soil under black nylon $(\mathrm{BN})$ at 0.05 $\mathrm{mm}$ thickness $\left(1.69 \mathrm{~J}^{\mathrm{m}-2} \mathrm{~K}^{-1} \mathrm{~S}^{-1 / 2}\right)$ was significantly higher than the control, while at a thickness of $0.15 \mathrm{~mm}$, both translucent whitish plastic $\left(1.44 \mathrm{~J}^{\mathrm{m}-2} \mathrm{~K}^{-1} \mathrm{~S}^{-1 / 2}\right)$ and black nylon $\left(1.43 \mathrm{~J}^{\mathrm{m}-2} \mathrm{~K}^{-1} \mathrm{~S}^{-1 / 2}\right)$ were similar with that of bare soil.

The variations in the thermal effusivities of soil under the different treatments may be attributed to the differences in the soil bulk densities (Oladunjoye and Sanuade, 2012).The increase in the exchange of thermal energy with the soil under the treatments (transparent nylon, translucent whitish plastic and black nylon) and the surrounding may be attributed to the lower bulk density which apparently increased the soil pore spaces. This increase in the soil pore spaces could have enhanced the quick dissipation of heat energy in the soil.

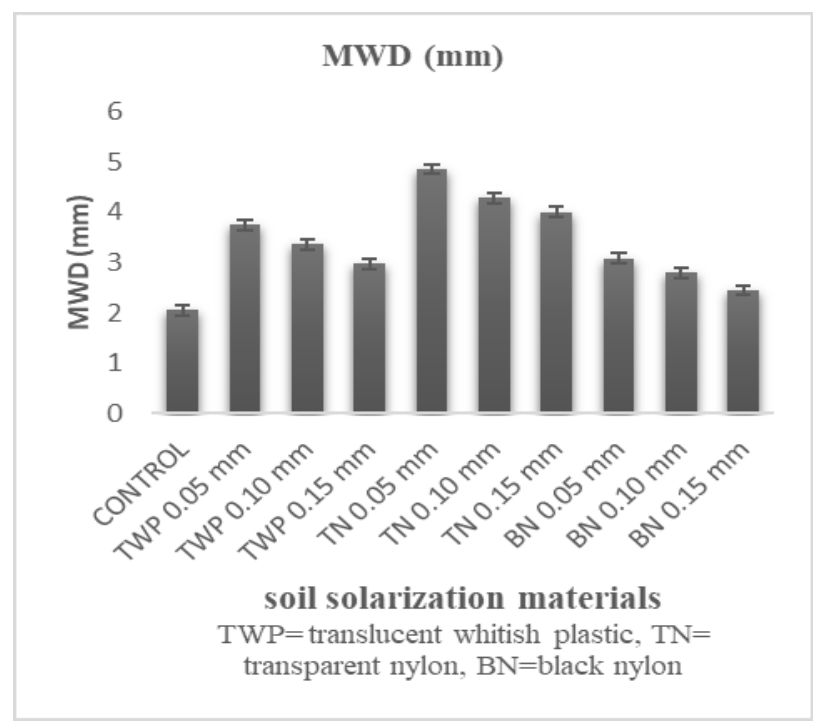

Figure 11: Effects of different soil solarization materials on mean weight diameter 


\section{Aggregate stability}

The aggregate stability of the soil measured only at the macro aggregate level using mean weight diameter is presented in Figure 11. From the result, the mean weight diameter (MWD) of the bare soil (control) was lower than the soil covered with nylon and plastic. The result showed that MWD ranged from $2.06-4.86 \mathrm{~mm}$ with a mean of 3.36 $\mathrm{mm}$. In Figure 11, it was observed that transparent nylon (TN) with a thickness of $0.05 \mathrm{~mm}$ had the highest stable aggregates $(4.86 \mathrm{~mm})$, while bare soil had the lowest $(2.06$ $\mathrm{mm})$. From the results, the soil structural stability under translucent whitish plastic (TWP) and transparent nylon (TN) were significantly $(p \leq 0.01)$ higher than the control (bare soil). However, the mean weight diameter of the soil under black nylon $(\mathrm{BN})$ at 0.05 and $0.10 \mathrm{~mm}$ thickness $(3.08$ and $2.80 \mathrm{~mm})$ were significantly $(p \leq 0.01)$ higher than the control, while at a thickness of $0.15 \mathrm{~mm}$ blike $(2.45 \mathrm{~mm})$ was similar with that of bare soil.

The higher structural stability observed in soil under transparent nylon, translucent whitish plastic and black nylon as compared with that of bare soil (control) may be attributed to the higher thermal transformation of iron and aluminium oxides, resulting from higher temperature (Figure 2) and thermal conductivity (Figure 6), which may have accelerated their role in acting as cementing agents for clay particles that then form strong silt-sized particles in the soil (Terefe et. al., 2008).

In addition, Khan et al. (2001) observed that a decrease in soil bulk density (Figure 4) could have improved the porosity and water holding capacity of the soil and possibly increased the aggregate stability. Furthermore, the probable stimulation of microbial activity from enhanced soil porosity and increased temperature (Figure 2), may have played a major role in the aggregate formation, which increase structure stability (Mohammed, 2015).

\section{Conclusion}

Variations in soil thermal properties and aggregate stability under different soil solarization materials was studied under field conditions in Nigeria. The principal objective was to study the effects of different soil solarization materials on soil thermal properties, organic matter and aggregate stability. The result showed that the measured soil properties varied among the different soil solarization materials. Translucent whitish plastic, transparent nylon and black nylon increased the amount of heat transmitted into the soil thereby increasing the temperature of the soil and the organic matter content. Higher soil bulk density and thermal diffusivity were observed in bare soil (control) than in the treatments. The plastic mulched soils recorded a higher aggregate stability that the bare soil. Soil-borne pathogens that may arise from continuous cultivation and use of the soil requires global attention to avoid destruction of the soil quality which can lead to food insecurity and environmental problems. Therefore, it is necessary to adopt soil management practices such as soil solarization techniques to stabilize soils under continuous use and improve the soil health by reducing the soil-borne pathogens.

\section{References}

Abu-Hamdeh, N.H. 2003. Thermal properties of soils as affected by density and water content. Biosystems Engineering 86 (1): 97-102.

Alrtimi, A., M. Rouainia and S. Haigh. 2016. Thermal conductivity of a sandy soil. Applied Thermal Engineering 106: 55-60.

Ahmed, A.G.A., K. Abbas, K. Akif, Y.K. Sui and N. Michael. 2017. Experimental investigation of thermophysical properties of soil using solarisation technology. American Journal of Applied Sciences 14 (7): 649-661.

An, K., W. Wang, Y. Zhao, W. Huang and L. Chen. 2016. Estimation from soil temperature of soil thermal diffusivity and heat flux in sub-surface layers. BoundaryLayer Meteorology 158: 473-488.

Blake, G.R. and K.H. Hartage. 2003. Bulk density. Pp.365375. In: Methods of Soil Analysis. Part 1. Physical and Mineralogical Properties, American Society of Agronomy, Madison, 101, USA.

Broadbent, F.E. 2015. Soil organic matter. Sustainable options in land management 2: 34-38.

Bronic, C.J. and R. Lal. 2005. Soil structure and management: a review. Geoderma 124: 3-22.

Canasveras, J.C., V. Barron, M.C. Del Campillo, J. Torrent and J.A. Gomez. 2010. Estimation of aggregate stability indices in Mediterranean soils by diffuse reflectance spectroscopy. Geoderma 158: 78-84.

Conant, R.T., M.G. Ryan, G.I. Ågren, H.E. Birge and E.A. Davidson. 2011. Temperature and soil organic matter decomposition rates-synthesis of current knowledge and a way forward. Global Change Biology 17: 339-404.

Dec, D., J. Dorner and R. Horn. 2009. Effect of soil management on their thermal properties. Revista De La Ciencia Del Suelo Y Nutricion Vegetation 9: 26-39.

Doring, T.F., M. Brandt, J. Heb, M.R. Finckh and H. Saucke. 2005. Effects of straw mulch on soil nitrate dynamics, weeds, and yield and soil erosion in organically grown potatoes, Field Crops Research 94: 238-249.

Evett, S.R., N. Agam, W.P. Kustas, P.D. Colaizzi and R.C. Schwartz. 2012. Soil profile method for soil thermal diffusivity, conductivity and heat flux: Comparison to soil heat flux plates. Advances in Water Resources 50: 41-54. 
Fang, C.M., P. Smith, J.B. Monorieff and J.U. Smith. 2005. Similar response of cabile and resistant soil organic matter pools to changes in temperature. Nature 436: 881883.

Fierrer, N., J.M. Gruine, K. McLauchlan and J.P. Schimel. 2005. Litter quality and the temperature sensitivity of decomposition. Ecology 86: 320-326.

Gardner, C.M.K., D. Robinson, K. Blyth and J.D. Cooper. 2000. Soil Water Content. Pp. 1-64 In: Soil and Environmental Analysis: Physical Methods, Revised and Expanded. $2^{\text {nd }}$ Ed. K.A. Smith (ed.). CRC Press, Boca Raton.

Grunwald, D., M. Kaiser, S. Junker, S. Marhan and H.P. Piepho. 2017. Influence of elevated soil temperature and biochar application on organic matter associated with aggregate-size and density fractions in an arable soil. Agricultural Ecosystem and Environment 241: 79-87.

Green, D.S., E.L. Kruger, and G.R. Stanosz. 2003. Effects of polyethylene mulch in a short-rotation, poplar plantation vary with weed-control strategies, site quality and clone. Forest Ecological Management 173: 251-260.

Hillel, D. 1998. Environmental Soil Physics: Fundamentals, Applications and Environmental Considerations. $1^{\text {st }}$ Ed., Academic Press, San Diego. Academic Press, London, $771 \mathrm{p}$.

Iqbal, M.M. 1986. Effect of different types of mulches on reduction of soil evaporation. Pakistan Journal of Soil Science 1(4): 21-26.

Juan, C.D.P. and B.K. Dean. 2002. Colored plastic film mulches affect tomato growth and yield vis changes in root-zone temperature. Journal of American Horticultural Science 127(1): 127-136.

Kader, A.M., M. Senge, A.M. Mohammad and N. Kimihito. 2017. Mulching type-induced soil moisture and temperature regimes and water use efficiency of soybean under rain-fed conditions in central Japan. International Soil and Water Conservation Research http://dx.doi.org/10.1016/j.iswer.2017.08.001.

Kamal, S. and A.K. Singh. 2011. Effect of black plastic mulch on soil temperature and tomato yield. Progressive Horticulture 43(2): 337-339.

Kemper, W.D., and R.C. Rosenau. 1986. Size distribution of aggregates in Methods of Soil Analysis. A. Klute (ed.). Part 1. $2^{\text {nd }}$ Ed. Agronomy Monograph 9:425-442.

Khaled, A.A. and N.H. Abu-Hamdeh. 2013. Specific heat and volumetric heat capacity of some saudian soils as affected by moisture and density. Proceedings of the International Conference on Mechanics, Fluids, Heat, Elasticity and Electromagnetic Fields (MFHEEF, 2013), Venice, Italy. September 28-30, 2013. Pp. 139-143.

Khan, F.U.H., A.R. Tahir and I.J. Yule. 2001. Intrinsic implication of different tillage practices on soil penetration resistance and crop growth. International Journal of Agricultural Biology 1: 23-26.

Khan, M.A., K.B. Marwat, A. Amin, A. Nawaz, R. Khan, H. Khan, and H.U. Shah. 2012. Soil solarization: An organic weed-management approach in Cauliflower. Communications in Soil Science and Plant Analysis 43: 1847-1860.

Liakatas, A., J.A. Clark and J.L. Monteith. 1986. Measurements of the heat balance under plastic mulches. Part I. Radiation balance and soil heat flux. Agriculture and Forest Meteorology 36: 227-239.

Liang, H., K. Hu, W. Qin, Q. Zuo and Y. Zhang. 2017. Modelling the effect of mulching on soil heat transfer, water movement and crop growth for ground cover rice production system. Field Crops Research 201: 97-107.

Łydżba, D., A. Różański, M. Rajczakowska and D. Stefaniuk. 2016. Random checkerboard based homogenization for estimating effective thermal conductivity of fully saturated soils. Journal of Rock Mechanical and Geotechnical Engineering 141: 04015016-04015016.

Mohammed, A.A. 2015. Impact of tillage and plastic mulching on some soil physical properties in relation with tomato yield. International Journal of Current Research 7(2): 12638-12641.

Moreno, M.M., A. Cirujeda, J. Aibar and C. Moreno. 2016. Soil thermal and productive responses of biodegradable mulch materials in a processing tomato (Lycopersicon esculentum mill.) crop. Soil Research 54: 207-215.

Nana, L., T. Fuqiang, H. Hongchang, L. Hui and M. Guanghui. 2016. Effects of plastic mulch on soil heat flux and energy balance in a cotton field in Northwest China. Atmosphere 7: 107-115.

Nelson, D.W. and L.E. Summers. 1982. Total carbon and organic matter. Pp. 359-580. In: Methods of Soil Analysis. A.L. Page (ed.). Chemical and Microbiological Properties. American Society of Agronomy, Maidson WI.

Ngailo, J.A. and S.F.C. Dechen. 2010. Effects of artificial soil surface management on changes of aggregate stability and other soil properties. African Journal of Environmental Science and Technology 4(9): 610-620.

Nigeria Meteorological Agency. 2015. Seasonal rainfall prediction for 2015. Nigeria meteorological publications. Maitana, FCT Abuja. Pg. 21.

Nwankwo, C. and D. Ogagarue. 2012. An investigation of temperature variation at soil depths in parts of Southern Nigeria. American Journal of Environmental Engineering 2(5): 142-147.

Ogban, P.I. and J.C. Obi. 2010. The relation between natural fallow and soil quality in Akwa Ibom state, southeastern Nigeria. Nigerian Journal of Agriculture, Food and Environment 6 (3): 34-43. 
Oladunjoye, M.A. and O.A. Sanuade. 2012. Thermal diffusivity, thermal effusivity and specific heat of soils in Olorunsogo powerplant, Southwestern Nigeria. International Journal of Research and Reviews in Applied Sciences 13(2): 502-521.

Oladunjoye, M.A., O.A. Sanuade and A.A. Olaojo. 2013. Variability of soil thermal properties of a seasonally cultivated Agricultural Teaching and Research Farm, University of Ibadan, South-Western Nigeria. Global Journal of Science Frontier Research Agriculture and Veterinary 13(8): 41-64.

Olugbenga, O. and C. Egbulem. 2015. Geological Setting, Compositional and Economic Appraisal of Clay-Shale Occurrence in Itu-Mbonuso/Iwere Area, South-Eastern Nigeria. Journal of Geography and Geology 7(1): 85-96.

Oluyamo, S.S., O.F. Famutimi, M.A. Adekoya and T.M. Aramide. 2016. Thermal properties of soil samples from coastal sand landform in Ilaje Local Government Area of Ondo State, Nigeria. Journal of Advanced Physics 11(10): 4137-4140.

Onwuka, B.M. 2016. Effects of soil temperature on some soil properties and plant growth. Scholarly Journal of Agricultural Science 6(3): 89-93.

Pramanik, P., K. Bandyopadhyay, D. Bhaduri, R. Bhatacharyya and P. Aggarwal. 2015. Effect of mulch on soil thermal regimes-A review. International Journal of Agriculture, Environment and Biotechnology 8: 645-645.

Qin, W., C. Hu and O. Oenema. 2015. Soil mulching significantly enhances yields and water and nitrogen use efficiencies of maize and wheat: A meta- analysis. Scientific Reports 5: 16210-16216.

Ramakrishna, A., H.M. Tam, S.P. Wani and T.D. Long. 2006. Effect of mulch on soil temperature, moisture, weed infestation and yield of groundnut in northern Vietnam. Field Crops Research 95:115-125.

Rubio, M.C., D.R. Cobos, R. Josa and F. Ferrer. 2009. A new analytical laboratory procedure for determining the thermal properties in porous media, based on the American standard D5334-05, Estudios en la Zona no Saturada del Suelo 9: 18-20.

Salomone, L.A. and J.I. Marlow. 1989. Soil Rock Classification According to Thermal Conductivity, EPRI CU-6482, Electric Power Research Institute, Palo Alto, CA.

Salomone, L., A. Kovacs, D. William and T. Kusuda. 1984. Thermal Performance of Fine-Grained Soils. Journal of Geotechnical Engineering, ASCE 110(3): 359-374.

Shah, S.S.H., A.U. Hassan, A. Ghafoor and A. Bakhsh. 2013. Soil physical characteristics and yield of wheat and maize as affected by mulching materials and sowing methods. Soil and Environment 32(1): 14-21.
Six, J., H. Bossuyt, S. Degryze and K. Denef. 2004. A history of research on the link between (micro) aggregates, soil biota, and soil organic matter dynamics. Soil Tillage Research 79: 7-13.

Six, J., E.T. Elliott and K. Paustian. 2000. Soil structure and soil organic matter. A normalized stability index and the effect of mineralogy. Soil Science Society of American Journal 64: 1042-1049.

Stapleton J.J. 2000. Soil solarisation in various agricultural production systems. Crop Protection 19: 837-841.

Stapleton, J.J. 1997. Solarization: an implementable alternative for soil disinfestation. Pp. 1-6. In: Biological Cultural Tests for Control of Plant Diseases. Vol. 12. APS press, St. Pauls. USA.

Stepanek, L.J., J.R. Brandel and M.O. Harrell. 2002. Assessment of micro environmental conditions related to the use of synthetics sheet mulches for protecting newly planted trees in semi-arid environments. Journal of Sustainable Agriculture 19(4): 15-31.

Terefe, T., I. Mariscal-Sancho, F. Peregrima, and R. Espejo. 2008. Influence of heating on various properties of sic Mediterranean soils. A laboratory study: Geoderma 143(3): 273-280.

Tong, B., Z. Gao, R. Horton and L. Wang. 2017. Soil apparent thermal diffusivity estimated by conduction and by conduction-convection heat transfer models. Journal of Hydrometeorology 18: 9-18.

Tokoro, T., T. Ishikawa, S. Shirai and T. Nakamura. 2016. Estimation methods for thermal conductivity of sandy soil with electrical characteristics. Soils Foundation 56(9): 27-36.

Usowicz, B., J. Lipiec, J.B. Usowicz and W. Marczewski. 2013. Effects of aggregate size on soil thermal conductivity: Comparison of measured and modelpredicted data. International Journal of Heat Mass Transfer 57(5): 36-41.

Wu, Y., F. Huang, Z. Jia, X. Ren and T. Cai. 2017. Response of soil water, temperature and maize (Zea may L.) production to different plastic film mulching patterns in semi-arid areas of northwest China. Soil Tillage Research 166(1): 13-21.

Xiukang, W., L. Zhanbin and X. Yingying. 2015. Effects of mulching and nitrogen on soil temperature, water content, nitrate-N content and maize yield in the Loess Plateau of China. Agricultural Water Management 161: 53-64.

Zawadzki, S., B. Dobrzan, S. Kowalin, T. Skawina and F. Ku. 1999. Gleboznawstwo. Podrecznik dla student tow. Wydanie IV poprawone i uzupelnione. Panstwowe Wydawnicto Rolnicze i Lesne. Warszawa, 559 p. 